JPE (Jurnal Pendidikan Edutama) Vol. 6 No. 1 Januari 2019

P-ISSN : 2339-2258 (Print) E-ISSN: 2548-821X (Online)

http://ejurnal.ikippgribojonegoro.ac.id/index.php/JPE

\title{
IMPLEMENTASI LESSON STUDY DALAM PEMBELAJARAN IPS DI SMP MUHAMMADIYAH KEMBARAN
}

\author{
Sakinah Fathrunnadi Shalihati \\ Pendidikan Geografi FKIP Universitas Muhammadiyah Purwokerto \\ Email: sakinahfs@ump.ac.id/queen.geo85@gmail.com
}

\begin{abstract}
Social Study is still considered a boring and less interesting subject in SMP Muhammadiyah Kembaran, it can be seen from the result of the examination in the odd semester in Academic Year of 2017/2018 showing that there were 5 students out of 13 students of the seventh grade who did not pass. The implementation of the lesson study aimed to improve the quality of teacher teaching and students' participation in learning. Lesson Study that had been implemented is a design in 3 cycles consisting of the activities of planning (plan), implementation (do) and reflection (see). The subjects of Lesson Study observation were social study teacher and students of the seventh grade in the even semester in Academic Year of 2017/2018 with a total of 13 students. Video, photos, discussions and observations were used to analyze the data, which were then analyzed by qualitative descriptive. The results obtained showed that students' interest and motivation experienced an increase in following social study learning, as evidenced by the increase in students' participation in completing the tasks given by the teacher.
\end{abstract}

Keywords: Lesson Study, Learning, Social Study.

Abstrak: Ilmu Pengetahuan Sosial (IPS) masih dianggap Mata Pelajaran yang membosankan dan kurang menarik di SMP Muhammadiyah Kembaran, hal ini dapat dilihat dari hasil ujian pada semester ganjil di Tahun Ajaran 2017/2018 yang menunjukkan bahwa terdapat 5 siswa dari 13 siswa kelas VII yang tidak lulus pada mata pelajaran ini. Pelaksanaan Lesson Study kali ini bertujuan untuk meningkatkan kualitas pengajaran guru dan partisispasi siswa dalam pembelajaran. Lesson Study dilaksanakan dengan desain 3 siklus yang terdiri dari kegiatan perencanaan (plan), implementasi (do), dan refleksi (see). Subjek pengamatan lesson study ini adalah guru IPS dan siswa kelas VII pada semester genap di Tahun Ajaran 2017/2018 dengan total 13 siswa. Video, foto, diskusi dan observasi digunakan untuk menganalisis data, yang kemudian dianalisis dengan deskripsi kualitatif. Hasil yang diperoleh menunjukkan bahwa minat dan motivasi siswa mengalami peningkatan dalam mengikuti pembelajaran IPS, yang dibuktikan dengan partisipassi siswa dalam menyelesaikan tugas yang diberikan oleh guru.

Kata Kunci: Lesson Study, Pembelajaran, Ilmu Pengetahuan Sosial

\section{PENDAHULUAN}

Tuntutan dunia internasional terhadap tugas guru memasuki abad ke-21 tidaklah ringan. Guru diharapkan mampu dan dapat menyelenggarakan proses pembelajaran yang bertumpu dan melaksanakan empat pilar belajar (learning to know, learning to do, learning to live together, learning to be) menurut Komisi Internasional UNESCO untuk Pendidikan, karena Pendidikan merupakan komunikasi terorganisasi dan berkelanjutan yang dirancang untuk menumbuhkan kegiatan belajar pada diri peserta didik Generasi Abad 21, dimana generasi ini memiliki kemampuan multitasking, terbiasa memperoleh dan memanfaatkan informasi dari dunia maya dengan tampilan multimedia yang lebih menarik. 
Pendidikan sebagai daya upaya untuk memajukan bertumbuhnya budi pekerti (karakter), pikiran (intelek) dan tubuh anak, bagian-bagian itu tidak boleh dipisahkan agar kita dapat memajukan kesempurnaan hidup anak-anak kita (Ki Hajar Dewantara (1962) dalam (Samho \& Yasunari, 2010)). Pesan dari Ki Hajar Dewantara, Bapak Pendidikan Nasional Indonesia ini sangat perlu untuk ditumbuhkan agar generasi masa depan Indonesia memiliki karakter dan kompetensi yang unggul, yang dimulai dari keluarga dan sekolah, yang kemudian akan membantu menguatkan peran Negara di kancah internasional, Negara dengan sekolah berkualitas tinggi memiliki kemampuan lebih tinggi dalam pertumbuhan ekonomi (Hanushek \& Wossmann, 2007).

Menuju terciptanya sekolah berkualitas tinggi, maka perlu adanya kerjasama dan hubungan yang saling menguntungkan dengan pihak yang mampu meningkatkan kualitas pengajaran di sekolah, salah satunya dalam bentuk kerjasama kemitraan guru dengan dosen Lembaga Pendidik dan Tenaga Kependidikan (LPTK). Bentuk kerjasama ini jika dioptimalkan dan dilakukan secara berkelanjutan akan memberikan solusi yang lebih komprehensif dalam meningkatkan mutu pengajaran dan pembelajaran baik bagi sekolah maupun LPTK.

Sebenarnya hubungan tersebut telah ada sejak dahulu, namun belum terjalin optimal, mengingat LPTK sendiri merupakan lembaga resmi yang mencetak calon guru. Kurangnya perhatian pada proses pengajaran dan pembelajaran, dukungan yang minim terhadap peningkatan kualitas pengajaran guru, pembinaan terhadap organisasi profesi yang tidak optimal, belum terbiasanya sekolah sebagai tempat belajar bagi pengembangan praktis pengajaran (guru) maupun peneliti pengajaran (dosen), serta kemitraan antara guru dan dosen yang baru sebatas hubungan program praktik mengajar mahasiswa, dan belum terbentuk secara sistematis, menjadi faktor terganjalnya pengembangan guru dan LPTK (Suratno, Ima, Zulkifly, \& Nuráini, 2010).

Hubungan kemitraan dapat melalui program peningkatan kualitas pembelajaran seperti Penelitian Tindakan Kelas (PTK) dan atau Lesson Study (Retnaningdyah, 2012) melalui Penugasan Dosen ke Sekolah (PDS), hal ini sejalan dengan apa yang sedang digaungkan oleh Direktorat Jendral Pembelajaran dan Kemahasiswaan bahwa kegiatan penugasan dosen ke sekolah merupakan kegiatan yang dapat memberikan dampak positif bagi LPTK maupun sekolah mitra (Nuril, 2018). Lesson Study sendiri merupakan model pembelajaran yang bertujuan membantu mengembangkan profesionalisme guru dan memberikan kesempatan bagi yang terlibat didalamnya untuk belajar dari akivitas yang terjadi di kelas, model ini memotivasi siswa untuk aktif dan belajar kolaboratif (Subadi, Khotimah, \& Sutarni, 2013).

Pidato Miriam Kronish, Kepala Sekolah SD John Eliot 1988-2002, Needham, Massachusetts, sekolah terbaik di Amerika Serikat, memberikan inspirasi bagi majunya Pendidikan di Amerika, menyampaikan:

"Masa depan Pendidikan di Amerika ditentukan oleh sebuah kekuatan, jika saja kami punya kekuatan, kekuatan tersebut adalah program utama di sekolah kami, yaitu pelatihan guru. Guru tidak hanya cukup membaca metode-metode belajar-mengajar terbaru. Guru harus dilatih, seperti halnya aktor atau penyair yang perlu berlatih. Setelah itu, guru baru bisa mengajarkannya kepada orang lain. Guru professional adalah gelombang masa depan Amerika..."(Chatib, 2009)

Muhammadiyah sebagai salah satu ideologi di Indonesia yang banyak 
berkecimpung pada bidang Pendidikan, memiliki watak yang moderat, mementingkan pendidikan dan pengajaran yang berdasarkan ajaran Islam, hingga Tahun 2010 Muhammadiyah memiliki 4.623 Taman Kanak-Kanak, 6.723 Pendidikan Anak Usia Dini, 15 Sekolah Luar Biasa, 1.137 Sekolah Dasar, 1.079 Madrasah Ibtidaiyah, 347 Madrasah Diniyah, 1.178 Sekolah Menengah Pertama, 507 Madrasah Tsanawiyah, 158 Madrasah Aliyah, 589 Sekolah Menengah Atas, 396 Sekolah Menengah Kejuruan, 7 Mullimin/Muallimat, $101 \quad$ Pondok Pesantren, 3 Sekolah Menengah Farmasi, 40 Universitas, 93 Sekolah Tinggi, 32 Akademik serta 7 Politeknik (Suharto, 2015).

Salah satu Sekolah Menengah Pertama (SMP) Muhammadiyah Kabupaten Banyumas adalah SMP Muhammadiyah Kembaran, sedangkan salah satu mata pelajaran dengan hasil kurang memuaskan adalah Ilmu Pengetahuan Sosial (IPS), menurut Kepala Sekolah Bapak Supriyanto, S.E, dari 13 siswa kelas VII yang lulus KKM dengan nilai 7,5 untuk mata pelajaran tersebut hanya 8 siswa di Semester Gasal Tahun Ajaran 2017/2018, sehingga perlu adanya kerjasama dengan LPTK terdekatnya yaitu Fakultas Keguruan dan Ilmu Pendidikan (FKIP) Universitas Muhammadiyah Purwokerto (UMP).

Kondisi ini sebagai ukuran yang menunjukkan keberhasilan pembelajaran yang berlangsung didalamnya, bukan pada ketidakmampuan siswanya, namun ada yang salah dengan cara mendidik dan memahamkan siswa, seperti pernyataan Chatib (2011) bahwa tidak ada siswa yang bodoh namun setiap siswa memiliki gaya belajar masing-masing, dan untuk memunculkan generasi masa depan berkualitas maka harus mencetak guru berkualitas, hal ini diungkapkan Anis Baswedan (Rektor Universitas Paramadina
Periode 2007-2011 dan Ketua Gerakan Indonesia Mengajar Tahun 2010) pada Pengantar buku Gurunya Manusia (Chatib, 2011).

IPS memang tidak diukur dalam Ujian Nasional, namun mata pelajaran IPS menurut Crosby (1964) sebagai studi yang memperhatikan bagaimana orang membangun kehidupan yang lebih baik bagi dirinya dan anggota keluarganya, bagaimana orang memecahkan masalah-masalah, bagaimana orang hidup bersama, bagaimana orang mengubah dan diubah oleh lingkungannya (Kenworthy (1981) dalam Naskah Akademik Kajian Kebijakan Kurikulum Mata Pelajaran IPS yang disusun Badan Penelitian dan Pengembangan Kurikulum (2007)).

IPS wajib diberikan kepada siswa SMP, jika berhasil diresapi ilmu ini sebagai bagian untuk membangun kehidupan lebih baik dan jika diaplikasikan dalam kehidupan nyata, maka semestinya akan terjadi peningkatkan hasil pada mata pelajaran yang lain, seperti mempelajari ilmu pokok lainnya yaitu Bahasa Indonesia, Bahasa Inggris, Matematika dan Ilmu Pengetahuan Alam, dimana ke empatnya merupakan mata pelajaran yang diujikan. IPS merupakan bahan kajian yang terpadu dari penyerdahanaan, adaptasi, seleksi dan modifikasi yang diorganisasikan dari konsep-konsep dan ketrampilanketrampilan Sejarah, Geografi, Antropologi dan Ekonomi (Puskur, 2001). Sebagai contoh materi mengenai Pasar, maka harus ditampilkan kapan atau bagaimana proses berdirinya (Sejarah), dimana pasar itu berdiri (Geografi), bagaimana hubungan antara orang-orang yang berada di pasar (Sosiologi), bagaimana kebiasaan-kebiasaan orang menjual atau membeli di pasar (Antropologi) dan berapa atau jenis-jenis barang yang diperjualbelikan (Ekonomi).

Berdasarkan latar belakang yang telah diuraikan tersebut, maka perumusan 
masalah dalam penugasan dosen ke sekolah kali ini adalah bagaimana implementasi lesson study dalam pembelajaran IPS di SMP Muhammadiyah Kembaran.

\section{METODE}

Kegiatan implementasi Lesson Study dalam pembelajaran IPS ini dilaksanakan di SMP Muhammadiyah Kembaran, yang merupakan salah satu sekolah Muhammadiyah yang terletak di Desa Kramat Kecamatan Kembaran Kabupaten Banyumas.

Satu-satunya Guru Pengampu Mata Pelajaran IPS di SMP Muhammadiyah Kembaran adalah Bapak Supriyatno, S.E., selain sebagai guru, beliau juga diamanahi sebagai Kepala Sekolah. Dalam implementasi Lesson Study, Bapak Supriyatno, S.E., sebagai guru model, sedangkan Dosen observer merupakan dosen yang ditunjuk untuk PDS yaitu penulis artikel ini sendiri. Subjek penelitian adalah siswa kelas VII Tahun Akademik 2017/2018, sejumlah 13 orang terdiri dari 5 putri dan 8 putra.

Lesson Study dilaksanakan di Semester Genap 2017/2018 mulai pada tanggal 9 April hingga 15 Mei 2018, dalam pelaksanaannya menggunakan rancangan dalam 3 siklus, dimana setiap sikus terdiri dari kegiatan perencanaan (plan), pelaksanaan (do) dan refleksi (see).

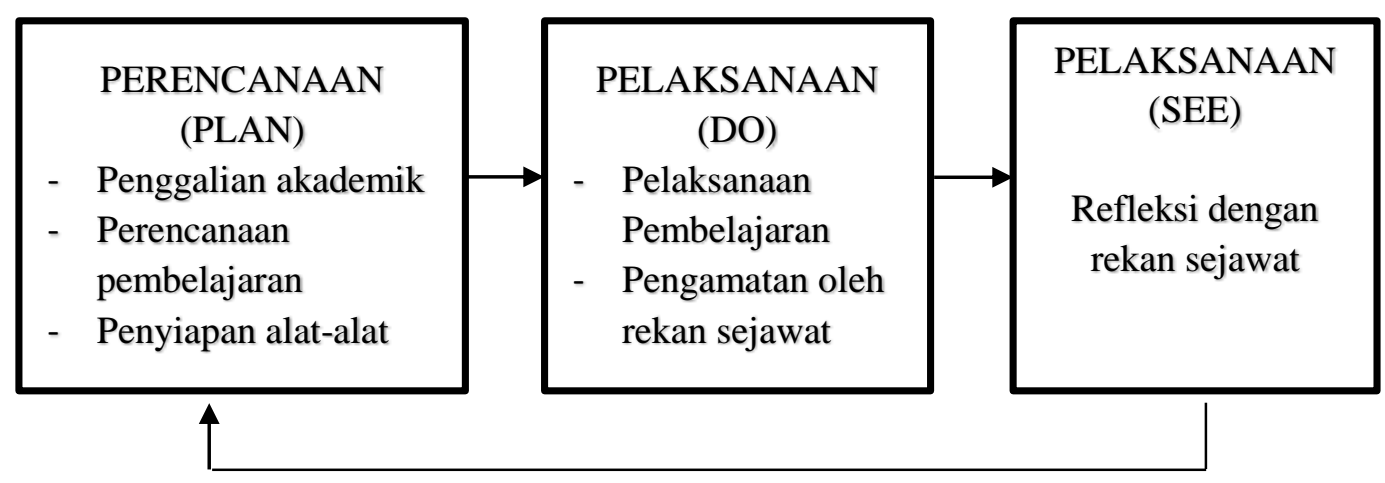

Gambar 1. Daur Lesson Study yang Terorientasi pada Praktik (Diadaptasi dari Saito, et (2005) dalam Syamsuri \& Ibrohim (2008))

Penjelasan setiap kegiatan pada gambar tersebut adalah sebagai berikut:

Perencanaan (Plan), Dalam proses perencanaan guru model dan observer mengkaji: (1) Kurikulum, termasuk didalamnya mencermati Kompetensi Dasar dan Standar Kompetensi, (2) Menentukan materi pembelajaran yang akan disajikan, biasanya materi yang dipilih untuk diangkat dan dijadikan topik adalah sulit bagi siswa dan sulit bagi guru, materi baru dalam krikulum, memerlukan metode dan media yang efektif, (3) Menyusun indikator dan pengalaman belajar siswa, (4) Menentukan metode yang sesuai, (5) Menentukan urutan proses pembelajaran, (6) Menyusun LKS (jika diperlukan), (7) Menyusun Evaluasi.

Pelaksanaan (Do), Ketika guru/dosen model yang telah disepakati sebagai pengajar melakukan proses pembelajaran, guru/dosen yang lain bertugas sebagai pengamat (observer). 
Tugas pengamat adalah mengobservasi bagaimana siswa belajar, bukan hanya bagaimana guru mengajar. Apa saja yang diobservasi oleh pengamat? (1) Interaksi siswa dengan siswa yang lain, baik dalam satu kelompok maupun antar kelompok, bagaimana efektivitas kerja kelompok adakah kegiatan saling membantu, (2) Interaksi siswa dengan guru sepanjang kegiatan belajar, (3) Interaksi siswa dengan media pembelajaran, apakah semua siswa menyentuh dan menggunakan media yang telah disiapkan guru atau siswa, (4) Interaksi siswa dengan sumber belajar atau dengan lingkungan sekitarnya, (5) Bagaimana gerak tubuh siswa yang mencerminkan aktif bekerja/belajar, (6) Apa yang dibicarakan dan didiskusikan oleh siswa, (7) Dan hal-hal lain yang berkaitan dengan aktivitas belajar atau ketidakaktifan dalam belajar.

Refleksi (See), Setelah pengamatan yang dilakukan observer pada sesi kegiatan pelaksanaan, kemudian dilanjutkan kegiatan refleksi dimana setiap observer membawa catatan hasil temuannya, yang akan dianalisis, diinterpretasikan dan dikemukakan untuk semua peserta, adapaun arahan yang akan disampaikan meliputi hal-hal berikut: (1) Mengemukakan data tentang kegiatan siswa belajar (siswa melakukan apa, pada saat apa kegiatan itu terjadi). Kegiatan yang dikemukakan tentunya adalah kegiatan siswa yang menarik atau yang khusus, miaslnya yang aktif, yang menjadi motor bagi yang lain, siswa yang pasif dan tidak dapat mengikuti pelajaran, dan lain sebagainya, (2) Mengapa siswa melakukan perilaku belajar seperti itu. Apa karena siswa tidak mendengar guru, LKS kurang jelas, siswa sulit mencerna pertanyaan guru, atau karena hal lain?, (3) Bagaimana jalan keluar mengatasi hal itu agar proses pembelajaran berlangsung efektif dan efisien?, (4) Pelajaran apa yag dapat dipetik dari kejadian tersebut?.

Teknik pengumpulan data dilakukan dengan menggunakan video, foto, diskusi dan observasi, dimana teknik pegumpulan data melalui video dan foto digunakan untuk mengambil dokumentasi suasana kelas saat kegiatan pembelajaran berlangsung, juga digunakan saat guru model dan observer melakukan diskusi, sedangkan teknik pengumpulan data melalui observasi digunakan untuk mengamati, merasakan, memahami dan mencatat hal-hal yang diperoleh saat kegiatan kelas dengan Lesson Study berlangsung.

Data yang diperoleh kemudian dianalisis dengan analisis diskriptif kualitatif, Menurut Sugiyono (2013) analisis diskriptif kualitatif diawali dari proses mencari dan menyusun secara sistematis data yang diperoleh dari hasil wawancara, catatan lapangan, dan dokumentasi, kemudian mengorganisasikan data yang diperoleh ke dalam kategori, menjabarkan ke dalam unit-unit, melakukan sintesa, menyusun ke dalam pola, memilih mana yang penting dan yang akan dipelajari, dan membuat kesimpulan sehingga mudah difahami oleh diri sendiri maupun orang lain. 


\section{HASIL DAN PEMBAHASAN \\ Deskripsi Sekolah}

SMP Muhammadiyah Kembaran telah terakreditasi B secara nasional, tertanggal didirikan pertama kalinya pada 16 Agustus 1979, dan secara resmi pada Surat Keputusan Pendirian Sekolah dengan nomor E1/3050/10/1979, sedangkan ijin oprasionalnya telah lebih dahulu dikeluarkan pada 01 April 1978 dengan SK ijin oprasional 00728/XXV/4P/78.

Kepala Sekolah yang saat ini menjabat adalah Bapak Supriyatno, S.E, dan jumlah guru terdapat 7 orang yang diberikan amanah sebagai pengajar dan juga membantu pada urusan administrasi sekolah. Kurikulum yang berjalan masih menggunakan Kurikulum Tingkat Satuan Pendidikan (KTSP) dengan penyelenggaraan 5 hari penuh dalam satu minggunya. Sedangkan jumlah total siswa terdapat 60 anak, yang terdiri dari 39 siswa laki-laki dan 21 siswa perempuan.

Berdiri diatas tanah seluas $745 \mathrm{~m}^{2}$, sekolah ini dilengkapi dengan 3 ruang kelas, 2 ruang sanitasi, 1 ruang kepala sekolah, 1 ruang guru, 1 ruang seni budaya, 1 ruang perpustakaan dan 1 ruang administrasi (Data Pokok Pendidikan SMP Muhammadiyah Kembaran, Tahun Ajaran 2017/2018).

Tabel 1. Rasio dan Persentase Proses Pembelajaran Semester Genap

Tahun Akademik 2017/2018

\begin{tabular}{llr}
\hline No. & Rasio dan Persentase & Keterangan \\
\hline 1. & Rasio Siswa Rombel & 20 \\
\hline 2. & Rasio Siswa Ruang Kelas & 20 \\
\hline 3. & Rasio Siswa Guru & 8.57 \\
\hline 4. & Persentase Guru Kualifikasi & 85.71 \\
\hline 5. & Persentase Guru Sertifikasi & 42.86 \\
\hline 6. & Persentase Guru PNS & 0 \\
\hline 7. & Persentase Ruang Kelas Layak & 100 \\
\hline
\end{tabular}

\section{Siklus 1}

Kegiatan PDS dalam bentuk Lesson Study di SMP Muhammadiyah Kembaran dimulai pada Hari Senin Tanggal 9 April 2018, Dosen observer melakukan kunjungan pertama untuk melakukan observasi terkait dengan kondisi sekolah, meliputi ketersediaan guru IPS, kurikulum yang sedang digunakan, jumlah kelas, jumlah siswa dan permasalahan dalam proses pembelajaran dan hasil pembelajaran IPS pada tahun sebelumnya.

Hasil yang diperoleh pada kunjungan pertama ini, menurut Bapak Supriyatno, S.E., kurikulum yang sedang berjalan adalah KTSP, terdapat fasilitas pendukung pembelajaran seperti proyektor portable, $\mathrm{CD}$ pembelajaran interaktif, papan tulis dan alat tulis lengkap, perpustakaan, kelas dengan pencahayaan maksimal, lapangan 
sekolah yang memadai yang dilengkapi dengan ring basket.

Sedangkan permasalahan dalam proses pembelajaran menurut Bapak Supriyatno, S.E., secara garis besar ditemukan beberapa hal sebagai berikut:

1. Kurangnya Percaya Diri, beberapa siswa kelas VII ini kurang memiliki perasaan percaya diri dalam kesehariannya di sekolah, ditunjukkan dari terlalu pendiam, atau ada yang terlihat membatasi diri bergaul dengan teman-teman sekelasnya, sering melamun saat kegiatan pembelajaran, sehingga mempengaruhi prestasinya dalam belajar.

2. Kurangnya Motivasi dan Semangat belajar, diantara beberapa siswa kelas VII terdapat siswa yang bekerja sepulang sekolah untuk membantu orang tuanya bekerja, bahkan hingga malam hari, sehingga ketika pada saat belajar dipagi harinya siswa tersebut merasa mengantuk dan akhirnya mempengaruhi kondisi motivasi dan semangatnya dalam belajar.

3. Belum maksimalnya intelektual, yang diakibatkan oleh kurangnya percaya diri, motivasi dan semangat dalam belajar siswa, sehingga penyerapan materi belajar menjadi tidak maksimal, dan mengakibatkan potensi kecerdasan yang dimiliki menjadi tidak optimal, terkesan malas-malasan dikelas, dan kurang bergairah untuk menuntut ilmu.

Setelah memperoleh informasi tersebut, kegiatan selanjutnya oleh Bapak Supriyatno, S.E. selaku guru model dan dosen observer adalah penentuan waktu pelaksanaan Plan, Do dan See setiap siklus, berikut untuk siklus 1.

a. Perencanaan (Plan)

Perencanaan ini dilakukan pada tanggal 30 April 2018 pukul 11.0012.00 oleh guru model dan observer, yang kemudian diperoleh hasil bahwa meateri semester 2 telah selesai disampaikan guru kepada siswa, sehingga kegiatan lesson study ini digunakan untuk mereview beberapa materi pada satu tahun yang dianggap sulit bagi siswa.

Kurikulum yang berlaku adalah KTSP, review pertama adalah pada materi pembelajaran bentuk muka bumi, yang terdapat pada Standar Kompetensi memahami lingkungan kehidupan manusia, dengan Kompetensi Dasar yang diharapkan tercapai adalah siswa mampu mendeskripsikan keragaman bentuk muka bumi, proses pembentukan dan dampaknya terhadap kehidupan, review pertama ini disampaikan pada 1 jam (45 menit) tatap muka mata pelajaran IPS. 


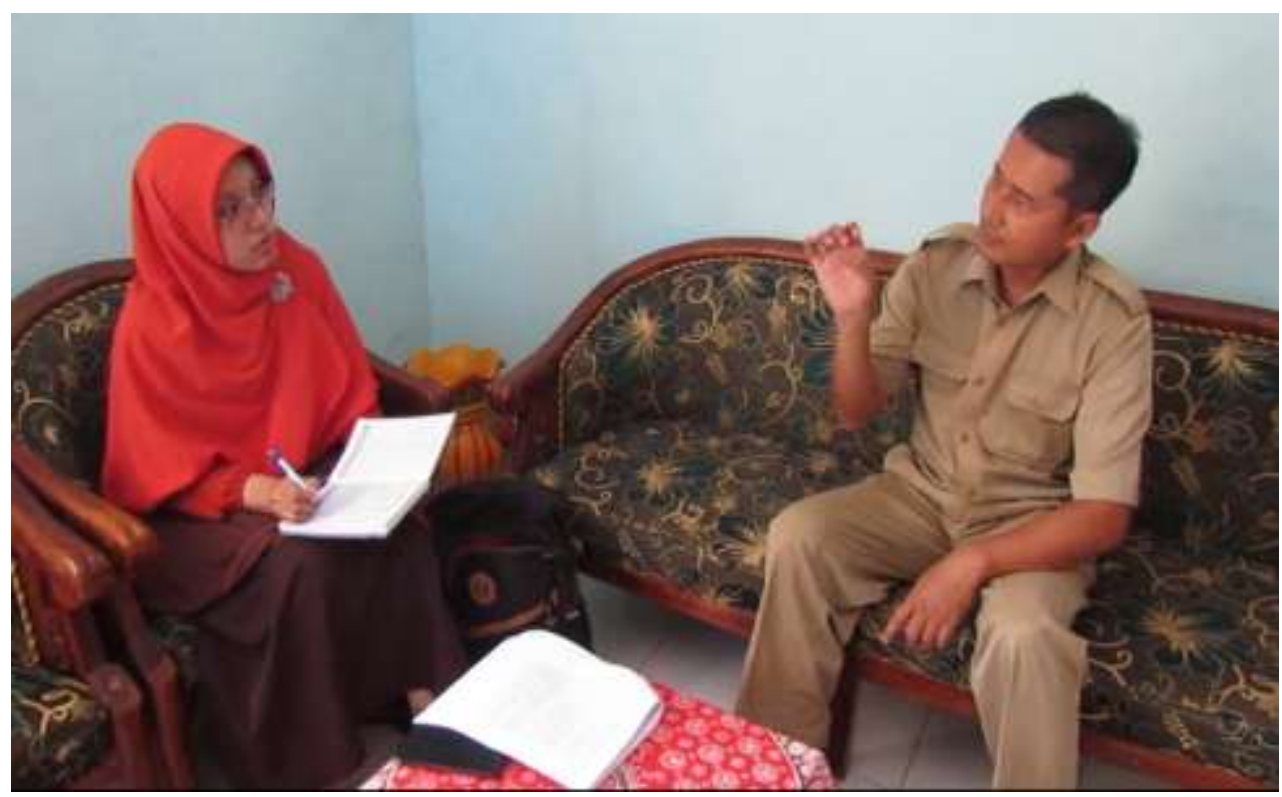

Gambar 3. Kegiatan Plan pada Siklus 1 (30 April 2018)

Sumber: Dokumen Pribadi

Kemudian indikator siswa berhasil dalam mengikuti pembelajaran jika mampu menyebutkan bentuk muka bumi, jenis tenaga endogen dan eksogen, sedangkan pengalaman belajar siswa yang akan diperoleh berupa mendengarkan materi, menulis, membaca, menjawab pertanyaan dari guru dan menyimpulkan materi.

Sedangkan metode yang digunakan oleh guru pada kegiatan Do adalah ceramah dan media gambar, untuk proyektor sedang rusak jadi tidak dapat digunakan untuk mendukung kegiatan pembelajaran. Adapun urutan proses pembelajaran dimulai dari guru membuka pembelajaran, menyampaikan apresepsi, ceramah, siswa menulis, siswa membaca, tanya jawab dan terakhir menyimpulkan materi. b. Pelaksanaan (Do)

Pelaksanaan dilakukan pada tangal 30 April 2018 pukul 12.3013.15 yang dilakukan oleh guru model, sedangkan observer mengamati dibarisan paling belakang, diperoleh hasil bahwa Guru model telah membuka kegiatan pembelajaran dengan berdoa bersama dan memberikan apresepsi kepada siswa dengan semangat yaitu meminta siswa berdiri dan saling memijat satu dengan yang lain. Hadir pada saat itu hanya 9 siswa dimana 4 orang siswa putri dan 5 siswa putra.

Kemudian memulai dengan menyampaikan tujuan pembelajaran dan menyampaikan review materi mengenai bentuk muka bumi, ada 4 siswi dan 1 siswa mengikuti pembelajaran dengan serius dan semangat, mereka membuat catatancatatan tersendiri dari hasil materi yang telah disampaikan oleh guru 
model, namun saat kegiatan ini terdapat 1 siswa yang tidur (Sapril) dan 1 siswa yang melamun, guru pun memberikan peringatan agar tidak tidur dikelas.

Kemudian selepas materi disampaikan dan diberi penguatan dengan gambar yang ada di papan tulis mengenai bentuk-bentuk muka bumi, tenaga eksogen dan endogen, selanjutnya siswa diberi pertanyaan mengenai jenis-jenis bentuk muka bumi dan sebab munculnya tenaga endogen serta eksogen oleh guru model, siswa diminta untuk mencari jawaban dari apa yang telah disampaikan guru model dan diperbolehkan mencari jawaban dari tambahan informasi yang berasal dari buku pegangan siswa.

Setelah siswa menyelesaikan pertanyaan dari guru model, selanjutnya siswa ditanya, tidak satu persatu, namun secara acak oleh guru, lalu guru menyimpulkan dan menutup kegiatan pembelajaran.

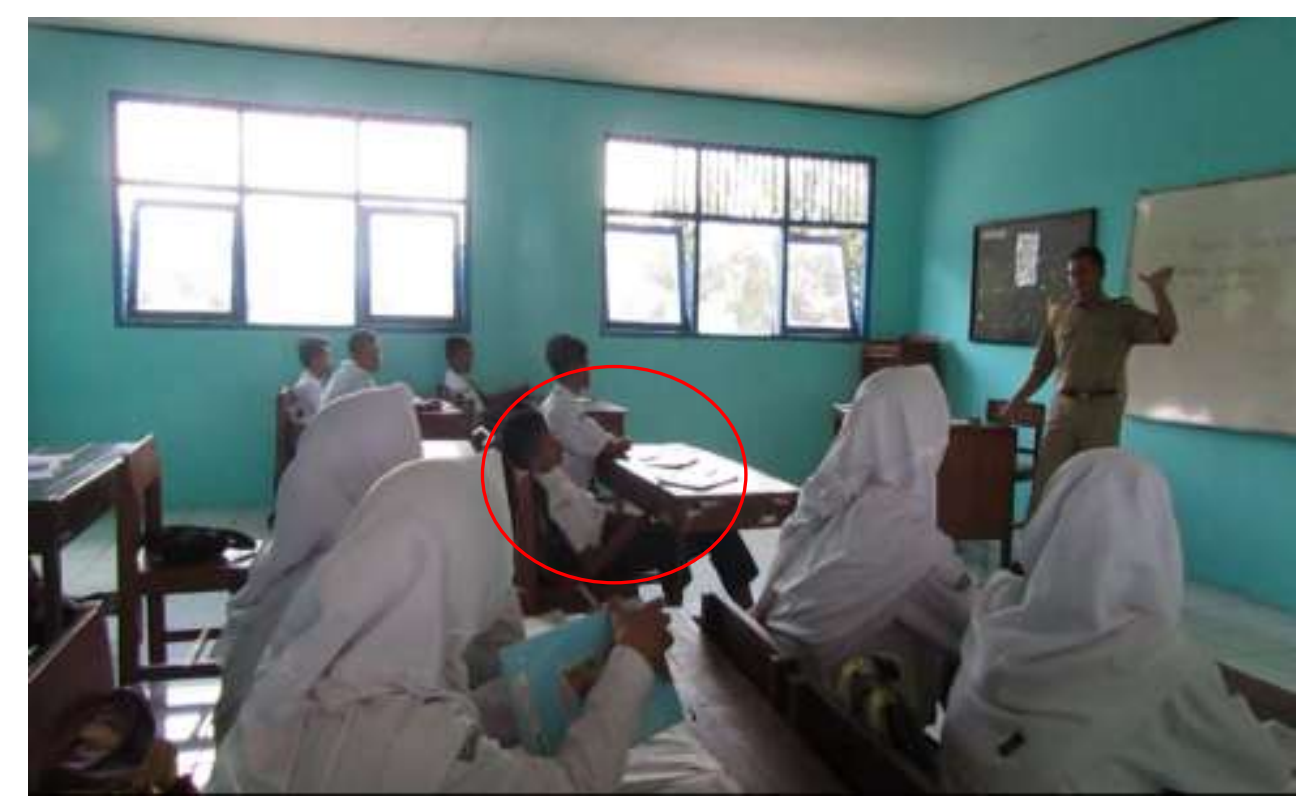

Gambar 4. Kegiatan Do pada Siklus 1 (30 April 2018),

terdapat siswa mengantuk pada saat mengikuti kegiatan pembelajaran Sumber:

Dokumen Pribadi

c. Refleksi (See)

Setelah dilaksanakannya Do, selanjutnya kegiatan refleksi yang dilaksanakan pada 14 Mei 2018. Dari hasil pengamatan observer, di pelaksanaan Do, guru terlalu mendominasi kelas, serta media pembelajaran yang digunakan juga kurang interaktif, sehingga membuat siswa kurang beraktivitas dan bergerak, mengakibatkan diantara siswa ada yang tertidur saat kegiatan pembelajaran. Kurang efektifnya metode pada Siklus 1 membuat guru model dan dosen observer perlu mengubah metode yang digunakan dalam pembelajaran. 


\section{Siklus 2}

a. Perencanaan (Plan)

Setelah diperoleh hasil yang kurang memuaskan di Siklus 1, guru model dan observer mencoba menggunakan metode serta pendekatan yang berbeda di Siklus 2. Perencanaan Siklus ke 2 dilaksanakan pada 14 Mei 2018, review materi pembelajarannya adalah Wisata Banyumas, dengan Standar Kompetensi yang digunakan adalah siswa dapat memahami kegiatan ekonomi masyarakat, dengan Kompetensi Dasar yang diharapkan dapat diperoleh adalah siswa mampu mendeskripsikan pola kegiatan ekonomi penduduk, penggunaan lahan dan pola permukiman berdasarkan kondisi fisik permukaan bumi, mendeskripsikan kegiatan pokok ekonomi yang meliputi kegiatan konsumsi, produksi, dan distribusi barang/jasa, mampu mendeskripsikan peran badan usaha, termasuk koperasi, sebagai tempat berlangsungnya proses produksi dalam kaitannya dengan pelaku ekonomi, serta mengungkapkan gagasan kreatif dalam tindakan ekonomi untuk mencapai kemandirian dan kesejahteraan.

Menggunakan metode diskusi kelompok, memanfaatkan media pembelajaran berupa video serta pendekatan saintifik $5 \quad M$ (Mengamati, Menanya, Menalar/Mencari Informasi, Mencoba menyimpulkan dan Menyajikan) b. Pelaksanaan $(D o)$

Guru model mengawali kegiatan pembelajaran dengan berdoa terlebih dahulu, menanyakan kabar siswa serta memberikan apresepsi berupa penyemangat untuk belajar. Siswa yang hadir berjumlah 12 siswa terdiri dari 5 siswa putri dan 6 siswa putra, hanya 1 siswa yang tidak dapat hadir. Guru memberikan pembukaan terkait dengan materi pembelajaran, kemudian meminta siswa menyiapkan alat tulis dan memberikan arahan untuk memperhatikan video Profil Kabupaten Banyumas yang akan ditampilkan serta meminta siswa untuk mencatat informasi penting pada video tersebut yang nantinya akan digunakan sebagai bahan diskusi kelompok.

Dari kegiatan melihat video, siswa belajar mengamati untuk memperoleh informasi penting terkait dengan wisata di Kabupaten Banyumas. Setelah selesai mengamati siswa dibagi menjadi 2 kelompok, kelompok pertama adalah semua siswa putra (6 siswa) dan kelompok kedua adalah semua siswa putri (5 siswa), yang ditugaskan sebagai ketua kelompok 1 adalah Sapril (siswa yang sebelumnya di Siklus 1 tidur dikelas), sedangkan kelompok 2 adalah Mei, kelompok putra mendapatkan tugas untuk mengidentifikasi dan menjelaskan 3 tempat wisata di Kabupaten Banyumas, sedangkan kelompok putri mendapatkan tugas 
mengidentifikasi dan menjelaskan 3 jenis makanan khas di Kabupaten Banyumas.

Nampak dalam perjalanan diskusi kelompok, untuk kelompok siswa putri lebih aktif dan kompak dalam berdiskusi, semua berbicara di dalam kelompoknya untuk menyampaikan pendapat, sedangkan kelompok putra berusaha aktif dikelompoknya, meskipun masih didominasi beberapa siswa saja. Setelah selesai berdiskusi guru model meminta ketua kelompok untuk menyampaikan hasil diskusi kelompoknya masing-masing. Saat akhir kegiatan guru model mengerucutkan kesimpulan dengan cara melibatkan siswa dengan mereview materi yang telah dilalui.

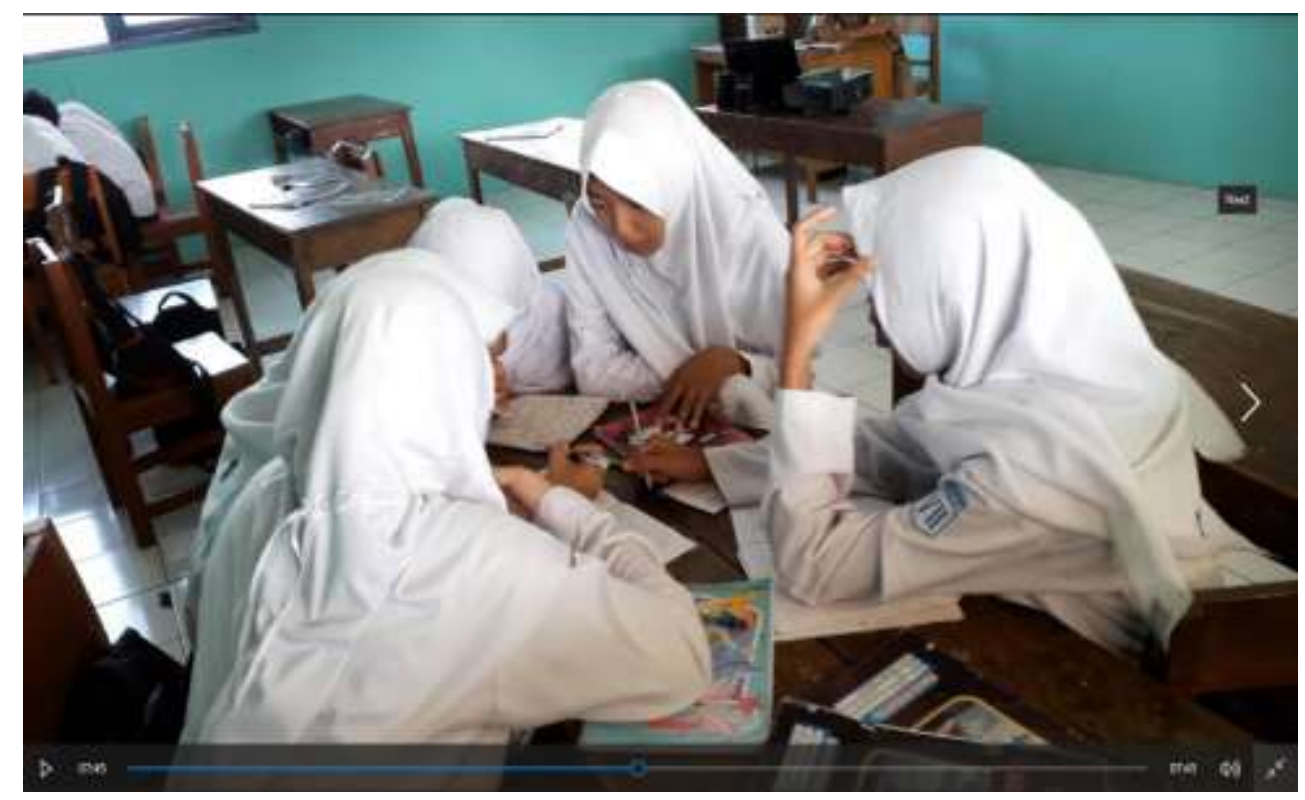

Gambar 5. Kegiatan Do Kelompok Putri Siklus 2 (14 Mei 2018 )

Sumber: Dokumentasi Pribadi

c. Refleksi (See)

Dari hasil pengamatan observer, siswa yang hadir dalam pelaksanaan Do ini menunjukkan lebih interaktif dalam mengikuti kegiatan belajar dibanding dengan saat di Siklus 1. Video pembelajaran yang ditampilkan cukup lama sehingga ada 1 siswa nampak bosan saat pemutaran video, kemudian saat diskusi kelompok, untuk kelompok putra mesih perlu pengarahan dalam pengkondisian meja dan kursi saat akan dimulainya diskusi, sedangkan kelompok putri sudah langsung terkondisikan, tanpa arahan dari guru model.

Saat berdiskusi masih didapati siswa putra ndlosor/meletakkan kepala dan tangan, seperti menunjukan kurangnya semangat atau motivasi dalam belajar. Guru model juga selalu melakukan peninjauan disetiap kelompok saat berdiskusi untuk mengetahui sejauh mana kegiatan diskusi kelompok yang telah dilakukan siswa. 
Dari hasil kegiatan siklus 2, dapat dinyatakan kegiatan pembelajaran berjalan dengan baik, namun masih didapati siswa yang kurang bersemangat, video yang ditampilkan juga perlu di kurangi waktunya, sehingga kegiatan diskusi dapat lebih lama dilakukan dengan komposisi pertanyaan lebih banyak.

\section{Siklus 3}

a. Perencanaan (Plan)

Perencanaan Siklus 3, didasari dari hasil refleksi yang telah dilakukan di siklus 2, dilakukan pada 15 Mei 2018. Masih menggunakan metode dan pendekatan saintifik $5 \mathrm{M}$, namun terdapat penataan tempat duduk yang berbeda dari siklus sebelumnya, di siklus sebelumnya satu meja terdapat 2 siswa, namun pada siklus ketiga ini setiap siswa berada di satu meja.

Review materi pelajaran pada tema Mitigasi Bencana, Standar Kompetensi yang digunakan adalah siswa mampu memahami lingkungan kehidupan manusia, dan Kompetensi Dasar yang diharapkan mahasiswa mampu mendeskripsikan keragaman bentuk muka bumi, proses pembentukan dan dampaknya terhadap kehidupan.

b. Pelaksanaan (Do)

Terlebih dahulu guru model mengawali kegiatan pembelajaran dengan membaca doa, memberikan apresepsi berupa motivasi dan semangat. Siswa yang hadir pada pelaksanaan Do kali ini berjumlah 13 siswa. Kemudian dilanjutkan dengan pemberian materi mengenai jenis-jenis bencana dan langkahlangkah mitigasi bencana, setelah dijelaskan siswa diminta untuk memperhatikan video mengenai jenis bencana yang terjadi di Dunia dan mitigasinya.

Saat memperhatikan video, siswa diminta memamati dan mencatat informasi yang ditemukan, setelah itu terdapat sesi tanya jawab, namun belum diminta untuk bertanya, namun tidak ada yang berani bertanya meski sudah diberi stimulus untuk bertanya oleh guru model.

Karena tidak ada yang bertanya, setelah itu guru model meminta mereka membuat laporan sederhana mengenai jenis bencana di Indonesia dan cara mitigasinya secara individu, untuk menuliskan hasil laporan sederhana tersebut siswa diperbolehkan berdiskusi dengan teman yang berada di bangku depan atau belakangnya, dari sini siswa belajar mencari informasi dari teman dan buku pegangan siswa.

Informasi yang diperoleh kemudian oleh siswa dituliskan dalam sebuah lembar kertas yang kemudian mereka juga diminta untuk menyimpulkan secara individu, setelah selesai kegiatan menyimpulkan, oleh guru model siswa diminta untuk mempresentasikan satu-persatu dihadapan teman-temannya. 


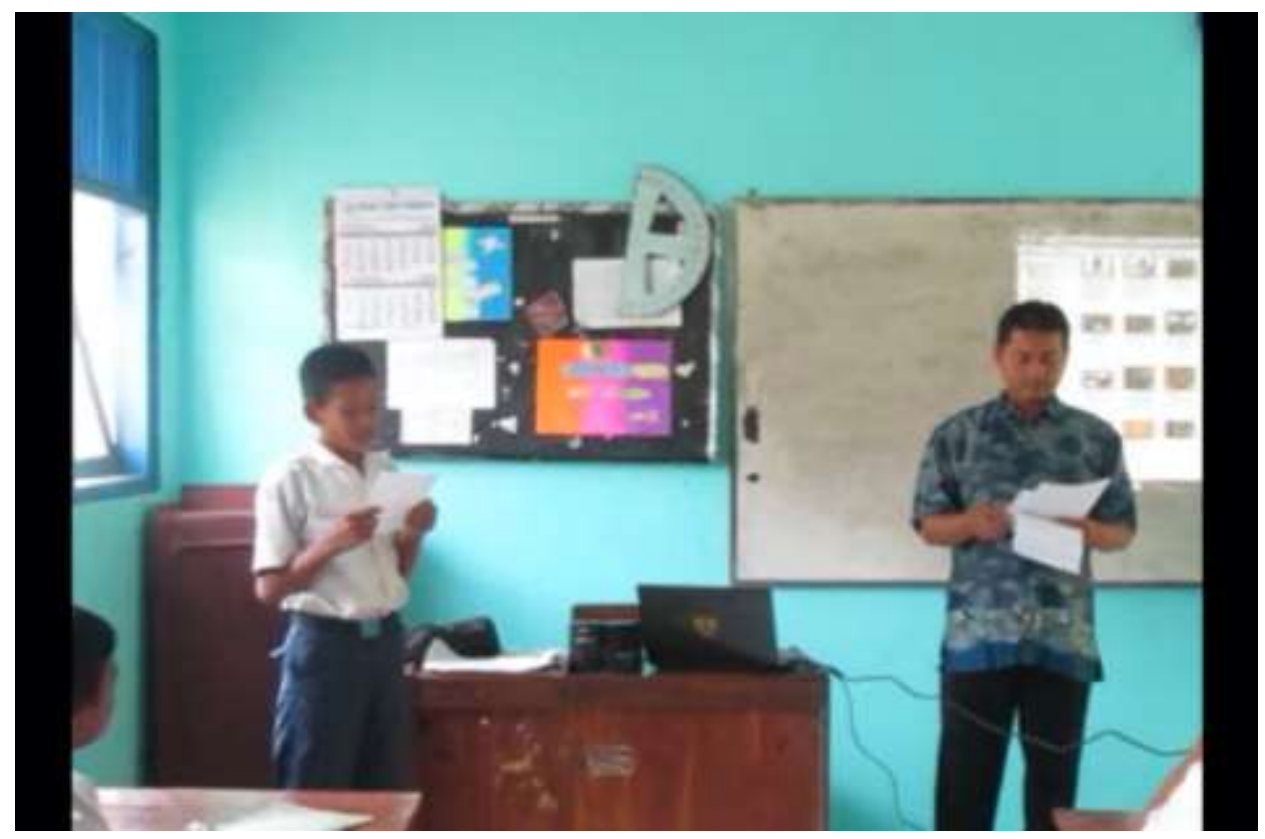

Gambar 8. Sapril saat Presentasi (15 Mei 2018)

Sumber: Dokumentasi Pribadi

c. Refleksi (See)

Hasil pengamatan observer menunjukkan bahwa selama kegiatan Do, siswa tampak antusias mengikuti kegiatan dan tidak didapati siswa yang tertidur dikelas lagi, video pembelajaran yang ditampilkan oleh guru model juga tidak memakan waktu cukup lama, hanya 15 menit saja. Saat sesi diskusi dan pembuatan laporan sederhana secara individu guru juga melakukan peninjauan ke setiap siswa, memberikan motivasi dan penghargaan berupa tepuk tangan kepada semua siswa yang telah mempresentasikan hasil laporannya.

Hasil kegiatan siklus 3, dapat dinyatakan baik, namun masih didapati rasa kurang percaya diri pada siswa dan siswi SMP Muhammadiyah Kembaran terbukti masih malu-malu ketika presentasi, suara yang keluar terlalu kecil sehingga tidak mudah didengar oleh siswa yang ada dideretan belakang.

\section{SIMPULAN}

Implementasi Lesson Study pada Mata Pelajaran IPS di SMP Muhammadiyah Kembaran menunjukkan hasil yang positif disetiap siklus yang dilakukan, nampak dari semangat belajar dan keakifan di kelas yang terus membaik.

\section{UCAPAN TERIMAKASIH}

Penulis mengucapkan terimakasih kepada jajaran Dekanat Fakultas Keguruan dan Ilmu Pendidikan Universitas Muhammadiyah Purwokerto atas tugas yang diberikan, serta dukungan dana pada Penugasan Dosen ke Sekolah dengan bentuk kegiatan Lesson Study Tahun Akademik 2017/2018, dan Agus Setiawan, S.Pd., 
selaku asisten yang bertugas dalam pengambilan dokumentasi kegiatan.

\section{DAFTAR RUJUKAN}

Badan Penelitian dan Pengembangan Kurikulum. (2007). Kajian Kebijakan Kurikulum Mata Pelajaran Ilmu Pengetahuan Sosial ( IPS ). Jakarta.

Chatib, M. (2009). Sekolahnya Manusia:Sekolah Berbasis Multiple Intelligences di Indonesia. Bandung: Kaifa, PT Mizan Pustaka.

Chatib, M. (2011). Gurunya Manusia. Bandung: Kaifa PT Mizan Pustaka.

Crosby, M. (1964). Curriculum Development for Elementary Schools in a Changing Society. New York: Heath.

Hanushek, E. a., \& Wossmann, L. (2007). Education Quality and Economic Growth. The International Bank for Reconstruction and Developmen. Retrieved from www.worldbank.org

Kenworthy, L. S. (1981). Social studies for the eighties, in elementary and middle schools (3d ed). New York: Wiley.

Nuril. (2018). Penugasan Dosen di Sekolah (PDS) Kuatkan Kemitraan LPTK dengan Sekolah. Retrieved from http://belmawa.ristekdikti.go.id/20 18/05/14/penugasan-dosen-disekolah-pds-kuatkan-kemitraanlptk-dengan-sekolah/

Retnaningdyah, P. (2012). Membangun Kemitraan Guru dan Dosen, Meningkatkan Inovasi Pembelajaran (2). Retrieved from http://tiwilioness.blogspot.com/2012/02/me mbangun-kemitraan-guru-dandosen.html

Samho, B., \& Yasunari, O. (2010). Konsep Pendidikan Ki Hadjar Dewantara dan TantanganTantangan Implementasinya Di Indonesia Dewasa ini. Bandung.

Subadi, T., Khotimah, R. P., \& Sutarni, S. (2013). A Lesson Study as a Development Model of Professional Teachers. International Journal of Education, 5(2), 102-114. https://doi.org/10.5296/ije.v5i2.38 31

Sugiyono. (2013). Metode Penelitian Pendidikan. Bandung: ALFABETA,cv.

Suharto, T. (2015). Gagasan Pendidikan Muhammadiyah dan NU sebagai Potret Pendidikan Islam Moderat di Indonesia. ISLAMICA: Jurnal Studi Keislaman, $9(1), \quad 81$. https://doi.org/10.15642/islamica.2 014.9.1.81-109

Suratno, T., Ima, N., Zulkifly, E., \& Nuráini. (2010). Implementasi 
Model Lesson Study di Tingkat

Sekolah Dasar: Studi Kasus di UPI

Kampus Serang. Pendidikan

Dasar, 13(April), 1-12.

Syamsuri, I., \& Ibrohim. (2008). Lesson

Study (Studi Pembelajaran).

Malang: FMIPA Universitas

Negeri Malang. 
114 JURNAL PENDIDIKAN EDUTAMA, Vol.6, No.1 Januari 2019 